The University of Maine

DigitalCommons@UMaine

Publications

Senator George J. Mitchell Center for Sustainability

Solutions

6-2015

\title{
Thinking past, thinking future: An empirical test of the effects of retrospective assessment on future preferences
}

\author{
Caroline L. Noblet \\ University of Maine, caroline.noblet@maine.edu \\ Mark W. Anderson \\ University of Maine \\ Mario F. Teisl \\ University of Maine - Main, teisl@maine.edu
}

Follow this and additional works at: https://digitalcommons.library.umaine.edu/ mitchellcenter_pubs

Part of the Environmental Studies Commons, and the Social Policy Commons

\section{Repository Citation}

Noblet, Caroline L.; Anderson, Mark W.; and Teisl, Mario F., "Thinking past, thinking future: An empirical test of the effects of retrospective assessment on future preferences" (2015). Publications. 103.

https://digitalcommons.library.umaine.edu/mitchellcenter_pubs/103

This Article is brought to you for free and open access by DigitalCommons@UMaine. It has been accepted for inclusion in Publications by an authorized administrator of DigitalCommons@UMaine. For more information, please contact um.library.technical.services@maine.edu. 
Thinking past, thinking future: An empirical test of the effects of retrospective assessment on future preferences

Caroline L. Noblet ${ }^{\square}$, Mark W. Anderson, Mario F. Teisl

School of Economics, The University of Maine, 5782 Winlsow Hall, Orono, ME 04469-5782, USA

* Corresponding author

E-mail address: caroline.noblet@ maine.edu (C.L. Noblet). 


\section{Abstract}

In recent work, we asserted that the largest group of stakeholders for sustainability science is future generations; yet intergenerational tradeoffs are often understudied. We proposed retrospective assessment as one potential means of clarifying what future preferences might be. Using a split-sample design we test the potential for retrospective assessment to influence citizens' preferences for future policy decision. We test the potential for retrospective assessment to yield increased or decreased support for policy. Our findings reveal context dependent public policy preferences where the presence of retrospective assessment significantly impacts citizens' preferences and outcomes appear strongly influenced by the attributes of the historical (or retrospective) scenario provided.

Keywords:

Sustainability science, Retrospective assessment, Citizen preferences, Context dependent 
In his 19th Century utopian novel Looking Backward, Edward Bellamy uses what we might now call retrospective assessment in telling the story of his idealized image of the future. The protagonist looks back from the year 2000 to his previous life in the late 1880s to explain how society could transcend the ills of industrial America. Bellamy's approach is an early literary version of backcasting (Robinson et al., 2011; Vergragt and Quist, 2011), imagining a future state and then thinking what viable path there might be from the present reality to that future state.

The relevance of similar retrospective thinking has been proposed in other contexts as well. Retrospective technology assessment was suggested as a technique for improving the methodologies of technology assessment (Tarr, 1976; Coates et al., 1982). The idea was to assess the current state of impacts of a mature or maturing technology and then determine by what technique those actual impacts might have been seen before the technology was adopted, using only the information available in that earlier time. Similarly, historical analysis was proposed in building community involvement in environmental protection (Pearce, 1999; Pesch and Garber, 2001) and in addressing complex environmental changes (Dreborg, 1996). The use of historical analysis in this manner reflected Heilbroner's (1960) pioneering notion of The Future as History; and history's role in public policy making continues to spark discussion (Guldi and Armitage, 2014).

Anderson et al. (2012) argued that retrospective assessment should play a role in sustainability as well. The contention was in response to neoclassical economists, who hold that preferences of 
those in the fu- ture are unknowable (Solow, 2000), and therefore the best we can do is assume that future preferences will be like those today. Additional assumptions made in neoclassical models about individual preferences include context independence and a self-regarding nature (Sugden, 2005; Gowdy, 2007). Thus in benefit cost analysis, the methodological tool for applying the neoclassical model to future analysis, values of benefits and costs are either derived from present market transactions or inferred through stated preference measures of current individual's values (Just et al., 1982; Anderson et al., 2015). Ecological and behavioral economists questioned such stability of preferences (Norton et al., 1998) finding that choices may be both context dependent and other-regarding, leading to a belief that we can know in broad ways about future preferences. Furthermore, knowing something about future preferences is imperative if sustainability is really to be about meeting the needs of those in the future as well as those today. As Norton (2005, pp. 315-329) argued, total ignorance of “... what effects of our activities can be predicted to be benign and which are likely to be harmful..." is not reasonable and that we can have "... a convincing basis for some expectations about what the people of the future will want..." (p. 326).

Since stakeholder engagement is central to sustainability (van Kerkof and Lebel, 2006), treating future citizens as stakeholders in present decisions is a legitimate and necessary contribution to sustainability science. In answering the question of how can future interests be represented in today's sustainability decisions, Anderson et al. (2012) posited that retrospective assessment is one means of understanding future stakeholders' reactions to the legacy of the current generation. The assertion was that by examining our reactions to past decisions, we better assess how the future will respond to decisions we make in the present. That is, instead of assuming that preferences for policy in the future will simply be like those in the present, we can better 
estimate future reactions to our current decisions by examining our reactions to past decisions. Thinking about the past more explicitly will help us better "give voice to the future" in our current policy deliberations.

There is, however, little empirical evidence about how retrospective assessment affects thinking about the future. Does this approach actually change people's thinking about how present decisions will be valued by future generations? Anderson et al. (2012) indicated that present decisions will be "perceived in the future with indifference, regret or gratitude" (page 4). The current research employs this framework to address the key question: Does retrospective assessment affect thinking about future preferences? Embedded in this question is the idea that thinking about the past through retrospective assessment is a form of framing (Levin et al., 1998) when such thinking is encouraged prior to thinking about the future.

We hypothesized that sustainability issues will be affected by retrospective frames in consistent ways. If individuals are asked first to think about past policy decisions for which they were future stakeholders and about which they feel gratitude, those people may think more positively about future policies that are analogous. We further hypothesized that past policy decisions viewed with regret will engender more negative thinking about analogous policy decisions proposed for the future. We used the concepts of gratitude and regret to frame policy preferences in order to reflect the temporal dimensions of preferences that might be influenced by retrospective assessment. As Gowdy and Howarth (2007) said, "Sustainability is not about what would be efficient for use to bequeath to the future, but rather what future persons would like for us to do today in order that their world might be more to their liking.". 
In order to address the effectiveness of retrospective assessment we designed two experiments to test whether preferences for public policy are changed, and if so, the nature of the change induced. This is the necessary first step in understanding how retrospective assessment might be used to include the interests of the future as stakeholders in current policy decisions. If policy preferences are shown to be changed by retrospective assessment, subsequent research would be needed to determine how it would aid in future stakeholder engagement. It is important to note that our investigations were not meant to manipulate respondents towards or away from a specific policy preference. Rather, the goal was to test whether retrospective assessment had an effect, a phenomenon for which we could find no empirical evidence in the literature. To conduct these experiments we undertook a mail survey of the general population of the State of Maine, in the Northeast corner of the United States, in the summer of 2013 using modified Dillman methods (Dillman et al., 2009). We began by following components of the proposed retrospective assessment process set forth by Anderson et al. (2012) where individuals are asked to think about a previous decision for which they may have preferences (i.e. feel regret, gratitude, or indifference).

Our original sample was split into two sub-samples, where one sample viewed questions about land conservation decisions in Maine and the other about energy policy decisions. The land conservation sub-sample ( $\mathrm{n}=179,30 \%$ response rate) was intended to test the effects of a gratefully acknowledged or "positive" retrospective assessment while the energy policy subsample ( $\mathrm{n}=198,31 \%$ response rate) was intended to test regret or "negative" retrospective assessment. ${ }^{1}$ 


\section{$2.1 \quad$ Land Conservation Experiment}

The policy issue considered in the land conservation experiment was the controversial offer of philanthropist Roxanne Quimby to donate approximately 70,000 acres (28,328 ha) of relatively undeveloped forest land, formerly held by private owners, in north central Maine to the Federal Government for the establishment of a National Park (Bangor Daily News, 2013a). This issue has been extensively covered in print and electronic media throughout Maine and the northeastern United States (see for example, Bangor Daily News, 2013a; Baker, 2013; Dill, 2012). Given this extensive media attention, we expected that respondents were likely to have been exposed to the issue and to the alternatives to a National Park establishment. The alternatives that had been extensively discussed in Maine were chosen for the response set in the experiment. Our control group $(\mathrm{n}=89)$ was given a brief description of the Quimby proposal (Fig. 1) and asked to select the statement closest to their feelings about the proposal. The respondents in this control group were not asked to do any retrospective assessment.

The story of the creation of Baxter State Park (BSP) is in many ways similar to the recent Quimby gift offer. BSP is located directly adjacent to Quimby's land. BSP was established early in the 20th Century by a former governor of Maine using his own personal wealth to accumulate privately held land that was then gifted to the State for the creation of a park (Rolde, 1997). Thus we feel this historical scenario is an apt frame for positive retrospective assessment to affect future thinking, particularly since BSP is an iconic public resource for many Maine residents. In both cases, BSP and the Quimby offer, there was a private individual offering to donate land purchased with private wealth for the establishment of a public park (one owned by 
the State of Maine the other to be owned by the Federal government). The temporal context was the major difference - BSP had been established for generations, the park from the Quimby gift was to be established in the future. The respondents in the treatment group $(n=90)$ were asked first to think about the establishment of Baxter State Park (Fig. 2), followed by the Quimby information and a question identical to the control group.

The shared baseline knowledge of Maine citizens regarding the historical and proposed policies yielded respondents able to participate in the experiments with limited provision of information about these scenarios in the experiments themselves. We appreciate that readers of this manuscript may not share this baseline and endeavor to provide additional information on the options presented to participants. The creation of a National Park would transfer control of the land, and choices made about the land, to the United States Federal government. National Parks are traditionally focused on preservation of resources, and do not alter the existing state of the land. Comparably, National Forests are also owned and controlled by the U.S. federal government, however their objective is to "sustain the health, diversity and productivity of the land" (National Forest Foundation, 2013), thus carefully managing the resources on the land (here for example, continuing to harvest timber). In contrast to the national options, State Parks are owned by, and controlled by, Maine state agencies. Similar to National Parks, these parks are preservation oriented. The final option presented to participants was private ownership of the land in question. While private ownership of timber land yields harvesting activity, a long standing tradition in Maine is public access for recreational purposes (hunting, camping, snowmobiling, hiking, etc.) to private land (Birch, 1982; Vail and Hultkrantz, 2000).

We expected that the majority of participants would express gratitude for the formation of 
Baxter State Park; thus the majority of respondents would select the first choice. We anticipated that this gratitude may in turn spillover into the consideration of Quimby's offer resulting in increased responses in the treatment group of gratitude for the Quimby offer. Thus, we expected that policy preferences would change in response to retrospective assessment where focusing on a positively viewed historical policy would more favorably dispose participants towards a similar proposal for the future.

\subsection{Energy Policy Experiment}

In the second component of the study we tested what we expected would be a negatively viewed historical energy policy; the corn-ethanol subsidy of the U.S. Federal government. We used this as an opportunity to employ retrospective assessment in examining preferences for investments in a new energy policy, here offshore wind electricity generation facilities being proposed for the State of Maine, a topic of current public policy debate (Kempton et al., 2005; Firestone et al., 2009). Similar to the Land Conservation Experiment, the potential for offshore wind in Maine received substantial media attention locally, regionally and nationally (see for example: Bangor

Daily News, 2013b; Energy.gov, 2013; Moretto, 2013); this coverage has been so substantial that it has been the subject of communication scholars (Smith and Lindenfeld, 2014).

Additionally, the current authors conducted prior research on the baseline knowledge of Maine citizens regarding corn-ethanol and found that $98 \%$ of residents were aware of corn ethanol as a fuel additive (Noblet et al., 2012). Thus our Maine based sample again yielded a set of participants with a shared baseline knowledge of our experimental scenarios.

The control group $(n=105)$ in this scenario was asked to respond to questions about potential 
offshore wind-power development in Maine (Fig. 3). The treatment group $(n=93)$ first viewed a brief introduction and then a question about the U.S. corn-ethanol subsidy policy (Fig. 4) followed by the offshore wind question. Here we expected that highly publicized negative outcomes associated with the corn ethanol subsidy would yield less support for the development of another new energy technology (here offshore wind). We expected that respondents would have negative or 'regretful' views of the federal corn ethanol subsidy for a number of reasons. First, our prior research on biofuels indicated that Maine citizens were willing to pay a weighted average premium for wood-based ethanol ranging from \$0.02-0.06 per gallon, with no premium for corn-based ethanol (Farrow et al., 2010). Second, Maine's elected officials were in favor of ending the subsidy (see Collins, 2011) and negative press regarding the subsidy was abundant in Maine (see Bangor Daily News, 2011; Portland Press Herald, 2011).

We now turn to analysis of our experiment where we examined differences between our control and treatment groups using descriptive statistics (i.e. frequencies, means, etc.) and inferential statistics including chi-square tests of distributional differences, t-tests and analysis of variance.

\section{Results}

\subsection{Land Conservation Experiment}

\subsubsection{Participants}

Table 1 contains demographic information from our respondents. Random assignment was used to allocate survey participants across conditions, thus demographic factors that may explain 
differences in responses to the scenario were tested across the two respondent groups (Table 1).

\subsubsection{Assessment of Past Decision}

To begin evaluating the effectiveness of our retrospective assessment experiment, we first needed to establish the assessment of the past decision. As noted, we anticipated that respondents would view the founding of Baxter State Park in a positive light; our results confirm this hypothesis as $89 \%$ of respondents in the treatment group indicated that they were "grateful" for the formation of the park (Table 2). We proceeded to test whether this positive view of a historical land-use change event would impact the evaluation of a proposed land-use change event, the Quimby offer.

\subsubsection{Impact of Retrospective Assessment on Decision Making}

Our experiment was designed to determine if retrospective assessment could be used as a tool to engage current citizens as proxies for future stakeholders by reminding them of their position as a 'future stakeholder' to a past decision. We hypothesized that retrospective assessment may yield changes to the distribution of responses, specifically looking for differences in the proportion of respondents who were 'grateful' or 'regretful' (here expressed as "wished ...."). We employed a chi-squared test of expected proportions between the treatment and control groups, where the control group represented our expected distribution (Table 3).

As hypothesized, differences in preferences between the treatment and control group exist, which may be, in part, ascribed to participation in retrospective assessment. However, the effect 
was not exactly as predicted. We had anticipated that those in the treatment group would be more likely to select response 1 in the Quimby scenario, indicating gratitude for the Quimby donation as a spillover from the overwhelming gratitude felt for the Baxter donation. However, we find that the percent of respondents selecting this category was consistent across both the treatment and control groups. Instead, we find that participants exposed to the retrospective assessment were more likely to agree with response 2, wishing that the Quimby lands were to be given as a State Park (relative deviation of 0.4$).{ }^{2}$ Additionally, respondents in the treatment group were less likely to select response 3 or 4 in comparison to the control group (relative deviation of -.02 and -0.4 respectively). Thus, our retrospective assessment prompt appears to have triggered two reactions: increased positivity for park creation and an increase in support for state management. These results indicate that retrospective assessment, as a tool for helping current stakeholders to express future stakeholder policy preferences, may work on a far more subtle level than we had hypothesized. Rather than responding to a blunt instrument of 'positive' retrospective assessment, respondents appear to be influenced by the attributes of the historical policy they were asked to assess. We see respondents in the treatment group who backcasted to their views on the formation of Baxter State Park were more likely to indicate that they wished Quimby would also establish a state park rather than any other potential uses. This attributebased decision making is consistent with Lancaster's Theory of the Consumer (1966) and is a key finding for our study.

\subsection{Energy Policy Experiment}

\subsubsection{Participants}


Random assignment was used to allocate survey participants across conditions. Demographic factors that may explain differences across responses to the scenarios were tested for differences across the two respondent groups (Table 4).

\subsubsection{Assessment of Past Decision}

We expected that respondents would have negative or 'regretful' views of the federal corn ethanol subsidy, thus setting the stage for a negative retrospective assessment. Table 5 shows that a slight majority of our respondents (56\%) expressed regret for the ethanol subsidy (responses 4-6). Interestingly, there is far less agreement among respondents, in comparison to the land conservation experiment, on the overall perception of the ethanol subsidy as well as the reasons which cause gratitude or regret. These results lead us to be increasingly interested in the role of the attributes of the retrospective assessment scenario on responses to the proposed policy.

\subsubsection{Impact of Retrospective Assessment on Decision Making}

Our chi-squared test of expected proportions between the treatment and control group reveals significant differences in distribution of responses (Table 6). Interestingly, our results again reveal the need for response categories that allow respondents to express the reason for their support (or regret) of a policy. Had we only included two responses, 'grateful' for the offshore wind development or 'regretful', we would not have captured the subtle divergence of responses evident in our data; a variation we may in part ascribe to retrospective assessment. We see that gratitude (regret) for investment in offshore wind energy is high (low) across both the control 
(81.1\% of respondents; $19.1 \%)$ and treatment groups $(79.5 \% ; 20.8 \%)$. The variance in

distribution between our treatment and control groups can be seen when examining reasons for a regretful response and gratitude regarding economic development. The treatment group was more likely to indicate regret at offshore wind development due to economic costs (relative deviation of 0.90 ); in contrast members of the control group were more likely to regret offshore wind investments due to the potential environmental costs (relative deviation -.30).

Respondents exposed to the retrospective assessment were also less likely to select response 3, gratitude for offshore wind investments due to the economic benefits.

\section{Discussion}

As a new tool for providing insight into the preferences of future stakeholders in sustainability science this initial experiment in employing retrospective assessment requires careful reflection. We are particularly cognizant that this work may serve as a guide post for future researchers seeking to enhance our understanding of the impacts of policy decisions on current and future stakeholders.

We first give consideration to the result that respondents were almost evenly split between gratitude and regret for the corn ethanol subsidy, when we expected a stronger negative reaction given our previous work (Farrow et al., 2010; Noblet et al., 2012), the association between the corn ethanol subsidies and higher food prices (Pimentel et al., 2009) and life cycle analysis findings that suggest that corn ethanol has only limited, if any, improvement in environmental profile over gasoline (Gomiero et al., 2010; Pimentel and Patzek, 2005). We hypothesize two potential explanations for these results that provide additional insight into the design and use of 
retrospective assessment. First, the proximity in time of the energy policy decision to our participants may be a factor which impacts retrospective assessment. Many of our participants were of voting age in the 1980's, during the origins of ethanol subsidies including the Energy Tax Act of 1978 (see McDonald, 1979) and Surface Transportation Assistance Act of 1983. Thus our participants were not left the legacy of corn-ethanol subsidies, but rather were observers of — and depending on their voting patterns, participants in — the decision making. It may be difficult for participants to reconcile the negative outcomes associated with the ethanol subsidy with their observation of/participation in the original policy choice. In contrast, participants in the land conservation experiment were indeed left the legacy of Baxter State Park as it was created from 1931 to 1962 . Second, we note that a relationship between the two energy technologies may not exist in the minds of citizens. Even respondents who expressed regret for corn-ethanol subsidies were often supportive of offshore wind development; half of the respondents who expressed regret for ethanol due to environmental reasons were grateful for the development of wind energy due to the environmental benefits.

A key component of understanding the potential for retrospective assessment to contribute to sustainability decisions is to recognize the multiple dimensions in which decisions are made. This work focused on the response citizens may have after considering a previous policy that left a legacy; whether this recall was positive, negative or indifference to the policy. Our work has shown that other dimensions also influence assessment. We find that not only are the specific attributes of the historical scenario important, but also potentially the unanimity of view regarding the scenario. In the land conservation experiment, we see almost unanimous support for the formation of Baxter State Park. However, in the energy policy experiment we see a divided response to the corn ethanol policy, perhaps due to the controversy which surrounded 
the adoption of this policy (and it's continued funding). The role of past controversial policies on future sustainability decisions warrants additional investigation.

\subsection{Hypothesized and Actual Limitations}

Anderson et al. (2012) hypothesized a number of potential limitations that an empirical retrospective assessment study may encounter; here we discuss evidence of these in our data.

\subsubsection{Limited Cognitive Abilities}

The scarcity of human cognitive abilities is a known limitation when evaluating individuals' ability to process and respond to information. Thus we know that processing is often susceptible to heuristics, including attentional bias (Gawronski et al., 2005). Individuals with closer connection to our scenarios are likely to respond differently than those who are emotionally or geographically removed. Individuals who commonly recreate in Baxter State Park and individuals who live near the Quimby land may all have experienced increased attentional bias when evaluating our land conservation experiment. Unfortunately, we were not able to fully employ Rawls' (1971) 'veil of ignorance' in our study. However, as previously noted we were able to collect data from participants with a shared baseline regarding these issues which may have mitigated some impacts present in more heterogeneous samples.

\subsubsection{Outcome vs. Process and System Justification Bias}

Individuals may not always judge a decision solely by its outcome, but rather through the 
process through which the decision was reached. As noted, our participants may (age dependent) have had the opportunity to vote for representatives who then passed the corn-ethanol subsidies. In this way, some of our participants were part of the process that enacted these subsidies. As noted, this may help explain the positive view of this policy expressed by some respondents as a form of system justification bias (Moshinsky and Bar-Hillel, 2010). In addition, Maine citizens were given the opportunity to vote on a state-bond to fund off- shore wind energy investment (Maine Secretary of State, 2010), again enabling participation in the process surrounding a decision they were asked to evaluate. In contrast, participants could not have been part of the process that created Baxter State Park due to the timeframe, but also the private nature of the land transactions. The Quimby scenario similarly excludes our respondents from participating in the process of this land-change decision: privately held land may be denoted if so desired with limited public input. Given that our intent was to model scenarios where a future stakeholder would be left a legacy, rather than have input into a decision, we recognize that our land conservation experiment was an example of a preferred retrospective assessment tool.

\subsubsection{Status Quo Bias}

Our results provide further evidence for the long-standing theory of status quo bias (Zajonc, 1968; Jost and Banaji, 2004). In initial responses to the Baxter scenario, $89 \%$ of respondents were grateful for the formation of this state park. However, when faced with a similar situation, where respondents could wish that a donation was earmarked for a new state park, only $31 \%$ indicated this option. This is consistent with the hypothesis that status quo bias may be a limitation encountered by retrospective assessment studies. Additionally, we acknowledge that our current framework does not adequately capture the potential for individuals to express 
'indifference' towards a past decision (nor, in their role as a proxy future stakeholder — towards a future decision).

\subsection{Key Insights and Future Recommendations}

Our study has provided valuable insight into the use of retrospective assessment as a tool to engage current citizens as proxies for future stakeholders. We have also contributed to the increasing body of literature dedicated to better understanding choice behavior; here we provide evidence of context dependent public policy preferences, where others have found context dependent private choices. Importantly, we have learned that careful consideration of the historical scenario that citizens retrospectively assess is warranted. We had originally hypothesized that exposure to a historical policy scenario that is traditionally viewed as 'positive' (i.e. formation of Baxter State Park) would increase the likelihood of responding in a positive manner to a proposed similar scenario (i.e. donation of Quimby land). However, our results suggest that individuals may not respond to the overarching frame associated with a historical scenario, in other words they do not necessarily view past decisions as only 'positive' or 'negative', but rather respond to the characteristics or attributes of the presented scenario. This reinforces a key lesson that variation in data is crucial in understanding the factors underlying preference behavior. Scenarios must include an opportunity for respondents to display the attribute based choices that may result from exposure to retrospective assessment.

\section{Footnotes}

1. Copies of all the surveys are available from the corresponding author.

2. The relative deviation is ametric for examining the level of difference between the observed 
and expected percentage (calculated by taking the difference between observed and expected and dividing by the expected percentage). 


\section{Acknowledgments}

This research was conducted as part of Maine's Sustainability Solutions Initiative, supported by the National Science Foundation award EPS-0904155 to Maine EPSCoR at the University of Maine. We are grateful to members of Session \#124 at the Western Economics Conference International 2014 and two anonymous reviewers for insightful comments on earlier versions of this paper. 


\section{References}

Anderson, M.W., Teisl, M.F., Noblet, C.L., 2012. Giving voice to the future in sustainability: retrospective assessment to learn prospective stakeholder engagement. Ecol. Econ. 84, 1-6.

Anderson, M., Teisl, M., Noblet, C., Klein, S., 2015. The incompatibility of benefit-cost analysis with sustainability science. Sustain. Sci. 10 (1), 33-41.

Baker, Billy, 2013. A feud as big as the great outdoors. The Boston Globe (Available at: http:// www.bostonglobe.com/magazine/2013/11/17/son-burt-bees-cofounder-leads-fight-for-mainenational-park/iQHv6w2s7fUJc6MBt6ZJSN/story.html. Accessed November 6, 2014).

Bangor Daily News, 2011. Where the tall corn goes. Available at: http://bangordailynews. com/2011/01/28/opinion/where-the-tall-corn-goes/ (Accessed November 6, 2014).

Bangor Daily News, 2013a. Editorial: "If Not a National Park, Then What?". Available at: http://bangordailynews.com/2013/02/21/opinion/if-not-a-national-park-then-what/? ref=search (Accessed April 18, 2014).

Bangor Daily News, 2013b. Politics: "LePage wants support for UMaine offshore wind project, not Statoil's, before he backs energy bill". Available at: http://bangordailynews. com/2013/06/04/politics/lepage-wants-support-for-umaine-offshore-wind-project-not-statoilsbefore-he-backs-energy-bill/ (Accessed November 6, 2014).

Birch, T.W., 1982. Forest-land Owners of Maine.

Coates, V.T., Fabian, T., McDonald, M., 1982. Nineteenth Century Technology—Twentieth Century Problems: A Retrospective Mini-Assessment. EPA-600/S9-82-011. U.S. Environmental Protection Agency, Washington, D.C.

Collins, S., 2011. Costly Ethanol Subsidies Should End. June 17, 2011. Available at: http:// www.collins.senate.gov/public/index.cfm/weekly-column?ID=9e8e66b6-0883-1e1c- 00a4- 
114978b2f9a0 (Accessed November 6, 2014).

Dill, C., 2012. Paper Mill Owner: Maine Woods National Park No Threat to Wood Supply. Huffington Post (Available at: http://www.huffingtonpost.com/cynthia-dill/maine- woodsnational-park_b_1148624.html. Accessed November 6, 2014).

Dillman, D., Smyth, J., Christian, J., 2009. Internet, Mail, and Mixed-mode Surveys: The Tai- lored Design Method. 3rd edition. Wiley, Hoboken, NJ.

Dreborg, K., 1996. Essence of backcasting. Future 28 (9), 813-828.

Energy.gov, 2013. Maine project launches first grid-connected offshore wind turbine in the U.S. Available at:, http://energy.gov/articles/maine-project-launches-first-grid- connected-offshorewind-turbine-us (Accessed November 6, 2014).

Farrow, K., Teisl, M.F., Noblet, C.L., McCoy, S., Rubin, J., 2010. Does Money Grow on Trees? People's Willingness to Pay for Cellulosic Wood Ethanol. Chapter in. Biofuel/Book 1. InTech Publishing.

Firestone, J., Kempton, W., Krueger, A., 2009. Public acceptance of offshore wind power projects in the USA. Wind Energy 12 (2), 183-202.

Gawronski, B., Deutsch, R., Seidel, O., 2005. Contextual influences on implicit evaluation: a test of additive versus contrastive effects of evaluative context stimuli in affective priming. Personal. Soc. Psychol. Bull. 31, 1226-1236.

Gomiero, T., Paoletti, M.G., Pimentel, D., 2010. Biofuels: efficiency, ethics, and limits to human appropriation of ecosystem services. J. Agric. Environ. Ethics 23 (5), 403-434. Gowdy, J.M., 2007. Toward an experimental foundation for benefit-cost analysis. Ecol. Econ. 63 (4), 649-655.

Gowdy, J.M., Howarth, R.B., 2007. Sustainability and benefit-cost analysis: theoretical as- sessments and policy options. Ecol. Econ. 63 (4), 637-638. 
Guldi, J., Armitage, D., 2014. The History Manifesto. Cambridge University Press. Heilbroner, R., 1960. The Future as History. Harper, New York.

Jost, Banaji, 2004. A decade of system justification theory: accumulated evidence of con- scious and unconscious bolstering of the status quo. Polit. Psychol. 25 (6).

Just, R.E., Hueth, D.L., Schmitz, A., 1982. Applied Welfare Economics and Public Policy.PrenticeHall, Englewood Cliffs, N.J.

Kempton, W., Firestone, J., Lilley, J., Rouleau, T., Whitaker, P., 2005. The offshore wind power debate: views from Cape Cod. Coast. Manag. 33 (2), 119-149.

Lancaster, K.J., 1966. A new approach to consumer theory. J. Polit. Econ. 132-157.

Levin, I.P., Schneider, S.L., Gaeth, G.J., 1998. All frames are not created equal: a typology and critical analysis of framing effects. Organ. Behav. Hum. Decis. Process. 76 (2), 149-188.

Maine Secretary of State, 2010. Maine citizen's guide to the referendum election. Available at:, http://www.maine.gov/sos/cec/elec/citizensguide.pdf (Accessed April 18, 2014).

McDonald, S.L., 1979. Energy Tax Act of 1978. Nat. Resour. J. 19, 859. Moretto, M., 2013. Details released about UMaine's politically charged offshore wind project. Bangor Daily News (November 6, 2013. Available at: http://bangordailynews. com/2013/11/06/business/details-released-aboutumaines-politically-charged- offshore-wind-project/?ref=relatedBox. Accessed April 18, 2014).

Moshinsky, A., Bar-Hillel, M., 2010. Loss aversion and status quo label bias. Soc. Cogn. 28 (2), 191204.

National Forest Foundation, 2013. What are the differences between National Parks and National Forests?. March 2013. Available at: http://www.nationalforests.org/blog/what- are-the-differencesbetween-national-parks-and-national-forests

Noblet, C.L., Teisl, M.F., Farrow, K., Rubin, J., 2012. Biofuels development in Maine: using trees to 
oil the wheels of sustainability. Maine Policy Rev. 22 (2), 56-65.

Norton, B., 2005. Sustainability: A Philosophy of Adaptive Ecosystem Management. University of Chicago Press, Chicago.

Norton, B., Costanza, R., Bishop, R.C., 1998. The evolution of preferences: why sovereign preferences may not lead to sustainable policies and what to do about it. Ecol. Econ. 24 (2), $193-$ 211.

Pearce, J., 1999. Historical reconstruction of ecological effects. Mar. Pollut. Bull. 38 (4), 233-234.

Pesch, C.E., Garber, J., 2001. Historical analysis, a valuable tool in community-based environmental protection. Mar. Pollut. Bull. 42 (5), 339-349.

Pimentel, D., Patzek, T.W., 2005. Ethanol production using corn, switchgrass, and wood; biodiesel production using soybean and sunflower. Nat. Resour. Res. 14 (1), 65-76.

Pimentel, D., Marklein, A., Toth, M.A., Karpoff, M.N., Paul, G.S., McCormack, R., Krueger, T., 2009. Food versus biofuels: environmental and economic costs. Hum. Ecol. 37 (1), 1-12.

Portland Press Herald, 2011. Vote to continue ethanol subsidies bad policy. Available at:, http://www.pressherald.com/2011/06/16/vote-to-continue-ethanol-subsidies-bad-policy_201106-16/ (Accessed November 6, 2014).

Rawls, J., 1971. A Theory of Justice. Belknap Press, Cambridge.

Robinson, J., Burch, S., Talwar, S., O'Shea, M., Walsh, M., 2011. Envisioning sustainability: recent progress in the use of participatory backcasting approaches for sustainability research. Technol. Forecast. Soc. Chang. 78 (5), 756-768.

Rolde, N., 1997. The Baxters of Maine: Downeast Visionaries. Tilbury House.

Smith, H.M., Lindenfeld, L., 2014. Integrating media studies of climate change into transdisciplinary research: which direction should we be heading? Environ. Commun. 8 (2), 179-196. 
Solow, R.M., 2000. Sustainability: an economist's perspective. In: Stavins, R.N. (Ed.), Economics of the Environment. WW Norton, New York.

Sugden, R., 2005. Coping with preference anomalies in cost-benefit analysis: a market simulation approach. Environ. Resour. Econ. 32, 129-160.

Surface Transportation Assistance Act of 1983, H.R. 6211, 97th Congress (United States). Pub. L. 97424. Available at: http://www.gpo.gov/fdsys/pkg/STATUTE-96/pdf/STATUTE-96- Pg2097.pdf.

Tarr, J.A., 1976. Retrospective technology assessment. Technol. Cult. 18, 655-658.

Vail, D., Hultkrantz, L., 2000. Property rights and sustainable nature tourism: adaptation and maladaptation in Dalarna (Sweden) and Maine (USA). Ecol. Econ. 35 (2), 223-242.

van Kerkof, L., Lebel, L., 2006. Linking knowledge to action for sustainable development. Annu. Rev. Environ. Resour. 31, 445-477.

Vergragt, P.J., Quist, J., 2011. Backcasting for sustainability: introduction to the special issue. Technol. Forecast. Soc. Chang. 78, 747-755.

Zajonc, 1968. Attitudinal effects of mere exposure. J. Pers. Soc. Psychol. 9 (2) 


\section{Figures}

Figure 1. Survey questions about proposed gift of land by Roxanne Quimby.

In the last decade, Roxanne Quimby purchased, with her own personal funds, over 100,000 of acres of forest land in Maine. These lands are currently managed by Elliotsville Plantation Inc. for, "....acquisition and conservation of land and the preservation of open space for the benefit of the public and the conduct of educational and stewardship programs." Ms. Quimby has in the past offered to give approximately 70,000 acres of these lands to the Federal Government for the establishment of a National Park.

Please indicate below your feelings about Quimby's private purchase of these forest lands and her subsequent offer to donate 70,000 acres to the Federal government to create a national park. Choose one statement below that is closest to your feelings:

1. I am grateful to Quimby for making this gift offer to the Federal government that would preserve this land for generations to come.

2. I wish that Quimby had offered these lands to the State of Maine for the creation of or the addition to a State Park rather than offering them to the Federal Government.

3. I wish that Quimby had offered these lands to the Federal Government for the creation of a National Forest and then be managed for multiple uses like other National Forest lands.

4. I wish that Quimby had not purchased these lands and then offered them to the Federal government. Rather, I wish the lands had been left in private hands and managed for commercial timber production. 
Figure 2. Survey question about Baxter State Park establishment.

Between 1931 and 1963 Percival Baxter donated over 200,000 acres of land around Mount Katahdin to the State of Maine for the creation of a park we now know as Baxter State Park. The money for these land purchases came from Governor Baxter's personal wealth, not from public funds. The lands were donated under the condition that they"... shall forever be kept for and as a State Forest and Public Park..." and "... shall forever be kept in their natural wild state and as a sanctuary for wild beast and birds."

Please indicate below your feelings about Baxter's private purchase of these forest land and subsequent donation to the state to create Baxter State Park. Choose one statement below that is closest to your feelings:

1. I am grateful to Baxter for making this gift to the State of Maine that preserves this land for generations to come.

2. I wish that Baxter had given these lands to the Federal Government for the creation of a National Park rather than giving them to the State of Maine.

3. I wish that Baxter had given these lands to the Federal Government for the creation of a National Forest and then be managed for multiple uses.

4. I wish that Baxter had not purchased these lands and then given them to the State of Maine. Rather, I wish the lands had been left in private hands and managed for commercial timber production. 
Figure 3. Survey questions about proposed off-shore wind development in Maine

University of Maine researchers, state and federal officials, and private firms are proposing the development of off-shore (deep water) wind power generating structures and on-shore facilities (transmission lines, sub-stations, etc.) to feed that electricity to the New England Power grid.

Please indicate below your feelings about your feelings about such off-shore wind power generational and transmission systems. Choose one statement below that is closest to your feelings:

1. Because of the environmental benefits, I am grateful that these entities are developing off-shore wind power generation and transmission facilities.

2. Because off-shore wind power reduces our dependence on imported oil, I am grateful that these entities are developing off-shore wind power generation and transmission facilities.

3. Because of the economic development benefits for Maine coastal communities, I am grateful that these entities are developing off-shore wind power generation and transmission facilities.

4. Because of the extra costs for consumers buying wind-power generated electricity, I regret that these entities are developing off-shore wind power generation and transmission facilities.

5. Because of the environmental costs, I regret that these entities are developing off-shore wind power generation and transmission facilities. 
Figure 4. Survey question about corn ethanol.

For nearly 30 years, there was a Federal tax credit to encourage the production of ethanol (alcohol) from corn. Ethanol was seen as desirable because it was a domestic fuel for automobiles and replaced imported oil. Also, adding ethanol to gasoline reduces some harmful air pollutants from burning gasoline. A Federal tax credit of 46 cents per gallon of ethanol produced was phased out in January 2012. Some critics of the subsidy for corn ethanol believe the fuel takes more fossil fuels energy to produce than the energy in the ethanol and that it has caused food prices to increase. While the tax credit has been eliminated, the government requires minimum amounts of ethanol in gasoline.

Please indicate below your feelings about the Federal programs to encourage production of corn ethanol as an automobile fuel. Choose one statement below that is closest to your feelings:

1. Because of the environmental benefits, I am grateful that the Federal government adopted programs to encourage the production of ethanol as an automobile fuel.

2. Because ethanol reduces our dependence on imported oil, I am grateful that the Federal government adopted programs to encourage the production of ethanol as an automobile fuel.

3. Because of the economic development benefits for corn farmers, I am grateful that the Federal government adopted programs to encourage the production of ethanol as an automobile fuel.

4. Because of the extra costs to consumers buying gasoline, I regret that the Federal government adopted programs to encourage the production of ethanol as an automobile fuel.

5. Because of the environmental costs of producing ethanol, I regret that the Federal government adopted programs to encourage the production of ethanol as an automobile fuel.

6. Because of the higher costs of food products because of producing corn ethanol, I regret that the Federal government adopted programs to encourage the production of ethanol as an automobile fuel. 


\section{Table 1}

Descriptive statistics of control and treatment groups, land conservation experiment.

\begin{tabular}{|c|c|c|}
\hline & Treatment & Control \\
\hline Gender (\% male) & 63 & 67 \\
\hline Age (mean; years) & 59.8 & 58.2 \\
\hline Income (median; $\$)^{\mathrm{a}}$ & 62,500 & 42,500 \\
\hline Education (years) ${ }^{\mathrm{a}}$ & 15.2 & 14.4 \\
\hline Children in household (\% with children in household) & 24 & 20 \\
\hline Years of Maine residency ${ }^{\mathrm{a}}$ & 40.6 & 48.0 \\
\hline Household size (\# of people) & 2.4 & 2.3 \\
\hline
\end{tabular}

a Statistically different between groups at $\mathrm{p}<.05$. 
Table 2

Evaluation of Baxter State Park formation, distribution of responses.

\begin{tabular}{ll}
\hline Response category & $\begin{array}{l}\text { Percent of } \\
\text { respondents }\end{array}$ \\
\hline $\begin{array}{l}\text { 1. I am grateful to Baxter for making this gift to the State of Maine } \\
\text { that preserves this land for generations to come. }\end{array}$ & 89 \\
2. I wish that Baxter had given these lands to the Federal \\
$\quad \begin{array}{l}\text { Government for the creation of a National Park rather than } \\
\text { giving them to the State of Maine. }\end{array}$
\end{tabular}


Table 3

Distribution of responses to land conservation experiment.

\begin{tabular}{|c|c|c|}
\hline \multirow[t]{2}{*}{ Response category } & \multicolumn{2}{|c|}{$\begin{array}{l}\text { Percent of } \\
\text { respondents }\end{array}$} \\
\hline & Treatment & Control \\
\hline $\begin{array}{l}\text { 1. I am grateful to Quimby for making this gift offer to the } \\
\text { Federal government that would preserve this land for } \\
\text { generations to come. }\end{array}$ & 31.1 & 31.5 \\
\hline $\begin{array}{l}\text { 2. I wish that Quimby had offered these lands to the State } \\
\text { of Maine for the creation of or the addition to a State } \\
\text { Park rather than offering them to the Federal } \\
\text { Government. }\end{array}$ & 43.3 & 29.2 \\
\hline $\begin{array}{l}\text { 3. I wish that Quimby had offered these lands to the } \\
\text { Federal Government for the creation of a National Forest } \\
\text { to be managed for multiple uses. }\end{array}$ & 11.1 & 14.6 \\
\hline $\begin{array}{l}\text { 4. I wish that Quimby had not purchased these lands and } \\
\text { then offered them to the Federal government. Rather, I } \\
\text { wish the lands had been left in private hands. }\end{array}$ & 14.4 & 24.7 \\
\hline Number of respondents ( $\mathrm{n}$ ) & 90 & 89 \\
\hline
\end{tabular}

$\chi^{2}=10.7, \mathrm{df}=3, p=.013$. 


\section{Table 4}

Descriptive statistics of control and treatment groups, energy policy experiment.

\begin{tabular}{lcc}
\hline & Treatment & Control \\
\hline Gender (\% male) & 62.1 & 58.8 \\
Age (mean; years) & 57.9 & 56 \\
Income (median; \$) & 62,500 & 62,500 \\
Education (years) & 15.5 & 15.0 \\
Children in household (\% with children in household) & 25.5 & 26.5 \\
Years of Maine residency & 39.3 & 37.9 \\
Household size (\# of people) & 2.9 & 2.5 \\
\hline
\end{tabular}

No statistical differences between groups. 


\section{Table 5}

Evaluation of federal corn-ethanol subsidies.

Response category Percent of

respondents

1. Because of the environmental benefits, I am grateful that the 10.8 Federal government adopted programs to encourage the production of ethanol as an automobile fuel.

2. Because ethanol reduces our dependence on imported oil, I am 25.8 grateful that the Federal government adopted programs to encourage the production of ethanol as an automobile fuel.

3. Because of the economic development benefits for corn farmers, $\quad 7.5$ I am grateful that the Federal government adopted programs to encourage the production of ethanol as an automobile fuel.

4. Because of the extra costs to consumers buying gasoline, I regret 12.9 that the Federal government adopted programs to encourage the production of ethanol as an automobile fuel.

5. Because of the environmental costs of producing ethanol, I regret that the Federal government adopted programs to encourage the production of ethanol as an automobile fuel.

6. Because of the higher costs of food products because of producing corn ethanol, I regret that the Federal government adopted programs to encourage the production of ethanol as an automobile fuel.

Number of respondents ( $\mathrm{n}$ ) 
Table 6

Distribution of responses to energy policy experiment.

\begin{tabular}{|c|c|c|}
\hline Response category & \multicolumn{2}{|c|}{$\begin{array}{l}\text { Percent of } \\
\text { respondents }\end{array}$} \\
\hline & Treatment & Control \\
\hline $\begin{array}{l}\text { 1. Because of the environmental benefits, I am grateful that } \\
\text { these entities are developing off-shore wind power } \\
\text { generation and transmission facilities. }\end{array}$ & 25 & 21 \\
\hline $\begin{array}{l}\text { 2. Because off-shore wind power reduces our dependence } \\
\text { on imported oil, I am grateful that these entities are } \\
\text { developing off-shore wind power generation and } \\
\text { transmission facilities. }\end{array}$ & 41 & 39.1 \\
\hline $\begin{array}{l}\text { 3. Because of the economic development benefits for } \\
\text { Maine coastal communities, I am grateful that these } \\
\text { entities are developing off-shore wind power generation } \\
\text { and transmission facilities. }\end{array}$ & 13.5 & 21 \\
\hline $\begin{array}{l}\text { 4. Because of the extra costs for consumers buying } \\
\text { wind-power generated electricity, I regret that these } \\
\text { entities are developing off-shore wind power generation } \\
\text { and transmission facilities. }\end{array}$ & 13.5 & 6.7 \\
\hline $\begin{array}{l}\text { 5. Because of the environmental costs, I regret that these } \\
\text { entities are developing off-shore wind power generation } \\
\text { and transmission facilities. }\end{array}$ & 7.3 & 12.4 \\
\hline Number of respondents ( $n$ ) & 93 & 105 \\
\hline
\end{tabular}

$\chi^{2}=10.98, \mathrm{df}=4, p=.026$. 